\title{
DASAR-DASAR KURIKULUM BERBASIS MULTIKULTURAL (Filsafat Kurikulum yang Mengitarinya)
}

\author{
Zainal Arifin, M.Pd.I \\ Dosen PAI STAI Miftahul Ula Nganjuk; Ketua LP Maarif Cab. Kab. Nganjuk \\ Zainalarifin061169@gmail.com
}

\begin{abstract}
Abstrak
Dalam dunia pendidikan, kurikulum menjadi tolok ukur dan rancangan keberhasilan pendidikan. Pendidikan yang baik ditandai dengan perumusan serta pengimplementasian kurikulum yang baik pula. Karena itu, agar dapat berdiri tegak kuat dan tidak roboh serta dapat tercapai tujuan pendidikan, kurikulum haruslah didasari dengan dasr filsafat yang kuat. Melalui metode kepustakaan (library research), penulis akan mengupas dasar kurikulum mengenai filsafat yang berada di dalamnya melalui sudut pandang multikulturalisme. Hasil dari kajian ini adalah penerapan multikulralisme dalam pendidikan sehingga menjadi "pendidikan multikultural" sangatlah tepat mengingat Indonesia adalah negara multikultur terbesar di dunia. Terlepas dari pro kontra pendidikan multikultural, sebelum menerapkan konsep pendidikan multikultural, tentunya terlebih dahulu kita formulasikan kurikulum yang berbasis multikultural dengan filsafat multikulturalisme sebagai roh kurikulum tersebut.
\end{abstract}

Kata Kunci: Multikultura, kurikulum, filsafat

\section{A. Pendahuluan}

Dalam kajian yang berjudul "dasar-dasar kurikulum berbasis multikultural" dangan anak judul filsafat kurikulum yang mengitarinya, kami sebagai penulis akan memulai bahasan kajian ini dengan bahasa pembahasan filsafat multikulturalisme. Dalam pembahasan yang pertama ini, kami akan menoba mengambil pemikiran Tilaar bahwa multikulturalisme lahir karena terpengaruh oleh teori keadilan John Rawls dan teori kebebasan Charles Taylor, sehingga akan dipaparkan kedua pemikiran tokoh tersebut, serta bagaimana proses kedua teori John Rawls dan Charles Taylor bertranformasi menjadi sebuah ideologi multikulturalisme.

Selanjutnya akan dibahas pula beberapa aliran filsafat pendidikan yang telah biasa kita kenal. Selain itu, penulis membagi filsafat pendidikan menjadi dua aliran pemikiran filsafat yaitu tradisional dan kontemporer. Dari kedua aliran itu akan 
muncul beberapa aliran filsafat ayang yang mana pada kajian kali ini, aliran tradisional akan dibatasi oleh aliran perenialism dan essentialism, sedangkan dalam aliran modern akan membahas aliran progressivism dan recontructionism serta eksistialism.

Dan pada bagian yang terakhir, penulis akan coba memberikan sebuah tawaran pemikiran tentang filsafat yang mendasari kurikulum berbasis multikultural. Akan tetapi, kami coba menggunakan sudut pandang multikultural yang terdapat dalam kurikulum 2013 dewasa ini. Sehingga dalam asumsi penulis bahwa dalam hal ini, kurikulum dapat dikatakan multikultural bila terdapat nilai-nilai multikultural di dalamnya.

\section{B. Filsafat Multikulturalisme}

Multikulturalisme sebagai filsafat terkadang ditafsirkan sebagai ideology yang menghendaki persatuan antara beberapa kelompok kebudayaan dengan hak dan status politik yang sama. Ideology multikulturalisme terkadang juga digambarkan sebagai upaya untuk menggambarkan kesatuan berbagai etnis masyarakat di suatu Negara ${ }^{1}$. Filsafat multikulturalisme - meminjam thesis yang di kemukakan oleh HAR Tilaartidak terlepas dari dua pemikiran filsul John Rawls dan Charles Taylor. Untuk itu akan dibahas pemikiran dari keduanya pada pembahasan setelah ini.

1. Multikulturalisme John Rawls

John Raws dalam A. Theory of Justice mengemukakan teori yang berupaya menghidupkan ide Social contract dan melanjutnya pemikiran Emanual Kahn serta mengemukakan suatu pemkiran alternatid dari ultilitarianisme. Menurut Raws, suatu masyarakat yang adil tidak hanya the greatest good for the gratest nummber, melainkan juga menekankan arti dari self interest. ${ }^{2}$

1 Moh. Suardi, Ideologi Politik Pendidikan Kontemporer, Yogyakarta: Deepublishing, 2015, HIm. 182

${ }^{2}$ HAR Tilaar, Multikulturalisme, Tantanagan-tantangan Global Masa Depan dalam Tranformsi Pendidikan Nasional, Jakarta: Grasindo, 2004,Hlm 75 
John Rawls mengemukakan konsep keadilannya sebagai satu konsep yang netral kultur. Menurut Rawls, untuk mewujudkan satu masyarakat yang teratur, maka prinsip-prinsip keadilan yang dilaksanakan harus bersifat fair. Prinsip keadilan tersebut harus menguntungkan setiap orang dan berdasarkan kesepakatan dari semua orang. Untuk itu, Rawls mengandaikan satu posisi asali, ditandai dengan kebebasan, kesamaan dan rasionalitas orang-orang yang ada di dalamnya diselubungi oleh satu ketidaktahuan terhadap hal-hal spesifik, kecuali hak-hak yang bersifat umum. Dengan demikian mereka dapat berpikir secara objektif, berpikir untuk keuntungan semua orang, untuk kebebasan dan kesamaan di antara semua pihak dalam masyarakat. Dengan prinsip egalitariannya, Rawls sangat menginginkan kesamaan di antara individuindividu, namun ia tidak menutup kemungkinan adanya ketidaksamaan-ketidaksamaan. Untuk itu ia menyikapinya dengan strategi maksimum, di mana ketidaksamaan terutama harus menguntungkan pihak yang paling tidak beruntung, tanpa merugikan pihak yang sudah beruntung dan semua posisi dan jabatan terbuka untuk semua orang. ${ }^{3}$

Dalam keadaan demikian, Rawls mengemukakan teorinya yang menghidupkan kembali social kontrak dan pendekatan etika sepanjang abad ke dua puluh.dalam posisi yang asli tersebut, Rawls mengemukakan dua prinsip yaitu:

a. Setiap manusia harus mempunyai sejumlah maksimum kebebasan individual dibandingkan dengan orang lain. Keadaaan seperti itu diperlukan untuk bersama-sama menikmati kemerdekaan yang juga dipunyai orang lain.

b. Setiap ketidaksamaan social ekonomi haruslah memberikan kemungjinann keuntungan bagi yang tidak memproleh keuntungan. Keadaan ini diambil dari pekerjaan dan posisi seseorang yang mempunyai akses serta kesemnpatan untuk itu. ${ }^{4}$

Setiap individu mempunyai dasar yang tak dapat dilanggar mengenai keadilan, bahkan kemakmuran suatu masyarakat tidak dapat melanggar hak

${ }^{3}$ Ridha Ahida, Konsep Keadilan pada Masyarakat Multikultural dilihat dari Perspektif John Rawls dan Will Kymlicka, dalam Perpustakaan Digital Universitas Indonesia, Hlm. 1

${ }^{4}$ HAR. Tilaar, Op. Cit, Hlm. 76 
tersebut. Oleh karena itu, suatu masyarakat yang berkeadilan, hak-hak yang dijamin oleh keadilan itu sendiri merupakan sesuatu yang tidak dapat tawar menawar politik maupun perhiotungan kepentingan social.

Manusia itu berada dibelakang cadar ketidak tahuannya, menentukan haknya dan kewajibannya. Liberalisme merupakan suatu doktrin politik, social, ekonomi yang menekankan kepada kemerdekaan individu, keterbatasan peran pemerintah, perkembangan social secara bertahap serta perdagangan. ${ }^{5}$

Penulis sangat mengapresiasi perspektif Rawls tentang ketidaksamaanketidaksamaan antara kelompok-kelompok kultural yang mana ketidaksamaan tersebut harus disikapi dengan melakukan redistribusi nilai-nilai sosial yang terutama menguntungkan kelompok-kelompok kultural yang telah tidak diuntungkan sebelumnya, tanpa merugikan kelompok kultural yang telah beruntung. Konsep keadilan Rawls sangat relevan untuk diterapkan pada ketidaksamaan-ketidaksamaan di bidang sosial dan ekonomi yang disebabkan oleh keanggotaan kultural. Dengan demikian, multikultural mengandung nilai keadilan yang menjadi nilai utama dalam menyikapi perbedaan yang ada.

2. Multikulturalisme Charles Taylor

Menurut Abbey filsafat Taylor lebih tepat disebut sebagai ontologi moral, yakni moral yang memiliki dimensi hakikinya sendiri, lepas dari pikiran manusia. Bahkan dapat dikatakan bahwa ia hendak melampaui paradigma yang berpusat pada manusia di dalam teori-teori tentang moralitas, dan kemudian memberi ruang bagi sumber-sumber tindakan moral yang berada di luar, atau melampaui, diri manusia. Dalam hal ini Taylor banyak mengikuti filsafat moral Iris Murdoch. Bagi Murdoch sendiri moral adalah tarikan dari Yang Baik itu sendiri, yang sifatnya lebih tinggi dari motivasi manusia biasa.

Charles Taylor yang menyatakan bahwa tindakan-tindakan kultural kita bukan hanya bersifat pribadi atau subyektif, melainkan dibentuk secara sosial.

${ }^{5}$ Ibid, Hlm. 76 
"Tindakan-tindakan kultural kita bersifat "intersubyektif", artinya kita tidak pernah bertindak sendirian. Makna tindakan kita adalah suatu makna yang dihayati bersama oleh orang lain; makna ini didasarkan pada asumsi-asumsi dan tindakantindakan kultural kita. Asumsi-asumsi yang berlainan mengenai bagaimana kebenaran harus dinyatakan oleh seorang yang memiliki kebajikan di dalam kehidupan bersama".

Dalam bukunya yang berjudul Multiculturalism and 'The Politics of Recognition' (1990) Charles Taylor memperluas pemikiran politik multikulturalisme dengan memperjelas multikulturalisme itu sebagai bentuk dorongan kepentingan politik kaum minoritas atau kelompok-kelompok subaltern atau kelompok kelas kedua (hak untuk menentukan diri sebagai minoritas/kelompok yang terpinggirkan. Hal tersebut ditambah lagi dengan adanya arus globalisasi dan abad informasi yang cenderung menghilangkan batas-batas (borderless) geografi dan budaya juga berperan penting mempercepat adanya budaya multikulturalisme. ${ }^{6}$

Charles Tylor mengemukakan pendapatnya bahwa kita harus menyadari bahwa persamaan hak dibawah hukum juga harus disertai dengan kemampuan kita untuk memahami bahwa kita sendiri adalah penulis dari hukum itu yang mengikat kita. Hal ini berati bahwa dengan jelas menunjukkan sistem yang mengikat kita tidak menghapuskan kondisi social yang berbeda beda juga terhadap peredaaan budaya. Dapat terjadi berbagai jenis konflik yang berasal dari diskursus tentang perbedaanperbedaaan tersebut serta resolusi secara demokratis atas perentangan tersebut ${ }^{7}$

Dengan demikian demokrasi konstitusional Charles Taylor menurut hemat penulis memberikan kepada anggota-anggotanya yang berkebudayaan minoritas, hak yang sama duduk bersama dengan kebuidayaan mayoritas. Sebagai contoh

\footnotetext{
${ }^{6}$ Yusuf Akhyar. Multikulturalisme dalam Perspektif Filsafat. Kajian dalam seminar "Student Circle" Pusat Studi Islam Paramadina dan Islamic College for Advance Studies (ICAS) Jakarta, 12 Maret 200

${ }^{77}$ HAR. Tilaar. Op. Cit, Hlm. 78
} 
yang tidak dapat menerapkan atau gagal dalam hal tersebut yakni masih ditemukannya kelompok seperti Afican Amerika dan Asia Amereica.

Pendapat Charles Taylor ini kemudian diterjemahkan ke dalam berbagai bahasa dan mendapat tanggapan yang luas dari kalangan akademikus seluruh dunia, termasuk Jiirgen Habermas dari Universitas Frankfurt. Habermas mengatakan bahwa perlindungan yang sama di bawah hukum saja belum cukup dalam suatu demokrasi konstitusional. Kita harus menyadari bahwa persamaan hak di bawah hukum juga harus disertai dengan kemampuan untuk mengerti bahwa kita sendiri adalah penulis (authors) dari hukum-hukum tersebut yang mengikat kita. Hal ini berarti bahwa dengan jelas menunjukkan sistem yang mengikat kita tidak menghapuskan kondisi sosial yang berbeda-beda juga terhadap perbedaan budaya. Dapat terjadi berbagai jenis konflik yang berasal dari diskursus tentang perbedaan-perbedaan tersebut serta resolusi secara dernokratis atas pertentangan-pertentangan tersebut. Habermas menganjur-kan agar supaya para warga negara dipersatukan oleh "mutual respect' terhadap hak-hak orang lain. ${ }^{8}$

Ketika pokok pikiran Charles Taylor dikemukakan, pada saat itu lembaga- lembaga publik, termasuk lembaga-lembaga pemerintah, sekolah-sekolah, universitas di bawah sorotan yang tajam karena gagal untuk menghargai identitas budaya yang khusus dari warga negaranya. Di Amerika Serikat hal ini dengan nyata kelihatan terhadap kelompok-kelompok African-American, Asian-American, Native American, dan pandangan terhadap wanita. Di dalam kehidupan politik dewasa ini muncul keinginan untuk diakui (recognition) terhadap hak hidup kelompok dalam masyarakat dengan kebudayaannya yang khas. Kebutuhan ini merupakan pendorong yang sangat kuat di belakang gerakan nasionalisme dalam politik. Gerakan ini menampakkan diri di dalam kehidupan politik, seperti tuntutan-tuntutan kelompok- kelompok minoritas, kelompok-kelompok subaltern, kelompok feminisme dan kelompok politik mutikulturalisme. ${ }^{9}$

${ }^{9}$ Ibid $t$, Hlm, 79 


\section{Dasar filsafat dalam Kurikulum}

Proses pendidikan adalah suatu proses pengembangan potensi peserta didik sehingga mereka mampu menjadi pewaris dan pengembang budaya bangsa. Melalui pendidikan berbagai nilai dan keunggulan budaya di masa lampau diperkenalkan, dikaji, dan dikembangkan menjadi budaya dirinya, masyarakat, dan bangsa yang sesuai dengan zaman dimana peserta didik tersebut hidup dan mengembangkan diri. Kemampuan menjadi pewaris dan pengembang budaya tersebut akan dimiliki peserta didik apabila pengetahuan, kemampuan intelektual, sikap dan kebiasaan, keterampilan sosial memberikan dasar untuk secara aktif mengembangkan dirinya sebagai individu, anggota masyarakat, warganegara, dan anggota umat manusia. Pendidikan juga harus memberikan dasar bagi keberlanjutan kehidupan bangsa dengan segala aspek kehidupan bangsa yang mencerminkan karakter bangsa masa kini. Oleh karena itu, tujuan pendidikan yang mereka pelajari tidak semata berupa prestasi besar bangsa di masa lalu tetapi juga hal-hal yang berkembang pada saat kini dan akan berkelanjutan ke masa mendatang.

Kurikulum merupakan suatu alat yang berfungsi sebagai sarana untuk mencapai tujuan pendidikan. Kurikulum dikembangkan dari pedoman kurikulum yang telah ditentukan. Pedoman ini akan digunakan sebagai penentu jalannya pencapaian tujuan pendidikan. Dalam hal ini yang dimaksud sebagai pedoman yaitu filsafat. Pada dasarnya ada beberapa filsafat yang dapat dijadikan sebagai dasar pengembangan kurikulum pendidikan. Tetapi dari beberapa filsafat, menunjukkan ketidak seragaman pemikiran tentang aspek yang terdapat dalam dunia pendidikan. Dalam artian, filsafat yang dianut akan mempengaruhi pandangan seseorang, terutama kurikulum yang dianut dalam suatu lembaga.

Demikian mendasarnya kedudukan filsafat, paling tidak filsafat memiliki empat fungsi dalam kurikulum:

1. Filsafat dapat menentukan arah dan tujuan kurikulum.

2. Filsafat dapat menentukan isi dan materi pelajaran kurikulum

3. Filsafat dapat menentukan strategi atau cara pencapaian tujuan 
4. Filsafat dapat menentukan tolok ukur keberhasilan proses pendidikan. ${ }^{10}$

Dalam kaca mata filsafat pendidikan dipengaruhi oleh berbagai aliran atau mazhab pendidikan yang telah dikenalkan dan dikembangkan oleh para ahli, yang mana aliran pemikiran filsafat dibedakan menjadi tradisional dan kontemporer. Dari kedua aliran itu akan muncul beberapa aliran filsafat ayang yang mana pada kajian kali ini, aliran tradisional akan dibatasi oleh aliran perenialism dan essentialism, sedangkan dalam aliran modern akan membahas aliran progressivism dan recontructionism serta eksistialism.

1. Perenialism

Menurut aliran ini, pendidikan sebagai proses mengembalikan keadaan sekarang. Perenialism berpengaruh baik teori maupun praktik bagi kebudayaan dan pendidikan zaman sekarang. ${ }^{11}$ Aliran Dari pendapat ini diketahui bahwa perenialism merupakan hasil pemikiran yang memberikan kemungkinan bagi sseorang untukk bersikap tegas dan lurus. Karena itulah, perenialism berpendapat bahwa mencari dan menemukan arah tujuan yang jelas merupakan tugas yang utama dari filsafat, khususnya filsafat pendidikan. Kebenaran menurut aliran ini terletak pada wahyu Tuhan dan caramenumbuhkan kebenaran tersebut terletak pada tugas guru. ${ }^{12}$

Perealism menghendaki agar pendidikan kembali pada jiwa yang mneguasai abad pertengahan, karena ia merupakan jiwa yang menuntun manusia hingga dapat dimengerti adanya tata kehidupan yang telah ditentukan secara rasional ${ }^{13}$. Aliran ini berpendapat bahwa Tugas utama pendidiakn adalah mempersiapkan anak didik kea rah kematangan. Matang dalam arti hiodup akalnya. Jadi, akal inilah yang perlu mendapat tuntunan kea rah kematangan tersebut. Sekolah

\footnotetext{
${ }^{10}$ Sholeh Hidayat, Pengembangan Kurikulum Baru,Bandung: PT. Remaja Rosda Karya, 2015, Hlm. 35

${ }^{11}$ Muhammad Noor Syam, 1986 Hlm. 154

${ }^{12}$ Made pidarta, Landasan Kependidikan, Stimulus Ilmu Pendidikan Bercorak Indonesia, Jakarta: Riena Cipta , 2013, Hlm. 91

${ }^{13}$ Muhaimin, Pengembangan Kurikuum Pendidikan Agama Islam, di Sekolah Madrasah dan Perguruan Tinggi, Jakarta: Pt. Raja Grafido Persada, 2005, Hlm. 80
} 
rendah memberikan pendidikan dan pengetahuan serba dasar. Dengan pengetahuan yang tradisional seperti membaca, menulis, dan berhitung, anak didik memperoleh dasar penting bagi pengetahuan-pengetahuan yang lain.

Dengan demikaian, jika aliran ini menjadi dasar dalam suatu kurikulum, para pendidik bertugas membimbing peserta didik menggunakan akalnya dalam kehidupan, dengan kata lain akal merupalam sesuatu yang essensial. Bagi aliran filsafat perelialism, karakter manusia secara umum adalah konsisten atau dengan kata lain tidak mengalami perubahan dan akan tetap sama sepanjang zaman. Oleh karena itu pendidikan yang diberikan kepada peserta didik haruslah sama. Dengan demikian, kurikulum yang memuat sejumlah mata pelajaran dapat disampaikan kepada semua peserta didik sepanjang waktu dan zaman. ${ }^{14}$

Hemat penulis titik tekan kurikulum yang menganut aliran ini terletak pada mata pelajaran, bukan pada peserta didik. Secara otomatis, guru akan menjadi sentral saat kegiatan pembelajaran di kelas. Untuk itu guru harus menempatkan komponen buku ajar, media, strategi dan lingkungan pembelajaran dan menguji secara seksaa relevansi kesemuaannya itu.

2. Esensialism

Aliran esensialism merupakan aliran pendidikan yang didasarkan pada nilainilai kebudayaan yang telah ada sejak awal peradaban umat manusia. Esensialism muncul pada zaman Renaisance dengan cirri-cirinya yang berbeda dengan progesivisme. Dasar pijakan aliran ini lebih fleksibel dan terbuka untuk perubahan, toleran, dan tidak ada keterkaitan dengan doktrin tertentu. Esensiliasm memandang bahwa pendidikan harus berpijak pada nilai-nilai yang memiliki kejelasan dan tahan lama, yang meberikan kestabilan dan nilai-nilai

\footnotetext{
${ }^{14}$ Abdullah Aly, Pendidikan Islam Multikultural Pesantren, Telaah terhadap Kurikulum Pondok Pesantren Islam Modern Assalam Surakarta, Yogyakarta: Pustaka Pelajar, 2011, HIm. 49
} 
terpilih yang mempunyai tata yang jelas. Tugas pendidika adalah pembawa nilainilai yang ada diluar ke dalam jiwa peserta didik ${ }^{15}$

Sekolah, sebagai tempat utama dalam pendidikan, didsain sedemikian rupa dengan pelajaran yang terstuktur agar mempercepat kebiasaan berfikir efektif. Sedangkan tugas utama guru adalah memberikan pendidikan dan pengajaran (pengetahuan) kepada anak didik. Dengan kata lain, keberhasilan anak dalam nidang akalnya sangat tergantung kepada guru, dalam arti pengajaran berpusat pada guru. ${ }^{16}$ Penganut aliran ini berpendapat bahwa belajar adalah menerima dan mengenal secara sungguh-sungguh nilai-nilai social angkatan baru yang timbul untuk ditambah, dikurangi dan diteruskan pada angkatan berikutnya

Apabila filsafat ini dijadikan landasan kurikulum, maka sekolah mempunyai misi untuk mengajarkan basic knowledge kepada para peserta didik dan dari sini, kurikulum di sekolah dasar harus memuat dasar-dasar ilmu yang membuat peserta didik dapat membaca dan menguasai aritmatika. Sedangkan di sekolah menengah, kurikulum bertujuan mengembangkan kompetensi tentang sejarah, sains, matematika dan bahasa. ${ }^{17}$

Menurut penulis, aliran ini kurang dapat mengeluarkan seluruh potensi peserta didik. Hal ini dikarenakan guru sebagai pusat dalam proses pembelajaran yang tidak jauh berbeda dengan perelialism. Dan juga peserta didik juga harus menerima mata pelajaran yang telah ditentukan oleh gueu tanpa bisa memilih mata pelajaran yang disukainya karena guru adalah fihak yang paling mengetahui apa yang harus diajarkan kepada peserta didik.

3. Progressivism

Aliran progresivisme mengakui dan berusaha mengembangkan asas progesivisme dalam sebuah realita kehidupan, agar manusia bias survive menghadapi semua tantangan hidup. Aliran progesivism telah memberikan

\footnotetext{
${ }^{15}$ Muhaimain, Op. Cit, Hlm. 80

${ }^{16}$ Made pidarta, Op. Cit, Hlm. 91

${ }^{17}$ Abdullah Aly, Op. Cit, Hlm. 50
} 
sumbangan yang besar di dunia pendidikan saat ini. Aliran ini telah meletakkan dasar-dasar kemerdekaan dan kebebasan kepada anak didik. Anak didik diberikan kebaikan baik secara fisik maupun cara berpikir, guna mengembangkan bakat dan kemampuan yang terpendam dalam dirinya tanpa terhambat oleh rintangan yang dibuat oleh orang lain ${ }^{18}$. Oleh karena itu, filsafat progesivisme tidak menyetujui pendidikan yang otoriter.

Progressivism mempunyai jiwa perubahan, relativitas, kebebabsan, dinamika dan perbutan nyata. Tidak ada kebutuhan yang pasti dan tidak ada pula kebenaran yang pasti. Semua itu bersifat relatif dan tujuannya pun tidak pasti. Maka alat untuk mencapai tujuan bisa berubah seiring berubanhnya tujuan. Dan oleh karena itu tujuan pendidikan adalah kontruksi pengalaman yang terus menerus agar peserta didik dapat berbuat sesuatu yangintelligent dan mampu mengandalkan adaptasi terhadap tuntutan lingkungan. ${ }^{19}$

Aliran ini berpendapat bahwa sekolah yang ideal adalah sekolah yang isi pendidikannya berintegrasi dengan lingkungan sekitar. Karena sekolah adalah bagian dari masyarakat. Dan untuk itu, sekolah harus dapat mengupyakan pelestarian karakteristik atau kekhasan lingkungan sekolah sekitar atau masyarakat. Sekolah merupakan bagian dari masyarakat, maka pendidikan berupaya memberikan kehidupan sosial yang lebih baik serta agen pembaruan masyarakat. ${ }^{20}$

Kurikulum yang meganut dasar filsafat progresif dikembangkan berdasarkan minat dan inisiatif peseerta didik. Dan titik tekan dari kurikulum yang menganut aliran ini adalah peserta didik dan peserta didik harus aktif dalam proses pendidikan serta harus dinamis dan tidak menunggu informasi dan pengetahuan yang disampaikan oleh guru. Guru di sini dipandang sebagai guide

\footnotetext{
18 Ali, 1990: 146)

${ }^{19}$ Muhaiimin, Op. Cit. Hlm. 80

${ }^{20}$ Made Pidarta, Op. Cit. Hlm. 93
} 
dan advisor. Dengan demikian, aktivitas di kelas haru fokus kepada pemecahan masalah dan atmosfir sekolah harus kooperatif dam demokratis. ${ }^{21}$

Bagi aliran filsafat progressivism, kurikulum haruslah terbuka dalam artian mata pelajaran yang dipelajari peserta didik harus disesuaikan dengan kebutuhan dan minat dari peserta didik. Dan di sini, kurikulum dewasa ini telah memberikan hak kepada peserta didik untuk memilih kelompok mata pelajran yang dirasa cocok untuknya melalui kelompok mata pelajaaran peminatan. Tetapi sayangnya ini hanya berlaku pada kurikulum yang ada pada sekolah menengah atas.

4. Rekonstruksionism

Kata Rekonstruksionism bersal dari bahasa Inggris reconstruct, yang berarti menyusun kembali. Dalam konteks filsafat pendidikan, rekonstruksionisme merupakan suatu aliran yang berusaha merombak tata susunan hidup kebudayaan yang bercorak modern. Aliran rekonstruksionisme pada prinsipnya sepaham dengan aliran perenialisme, yaitu berawal dari krisis kebudayaan modern. Menurut Muhammad Noor Syam, kedua aliran tersebut memandang bahwa keadaan sekarang merupakan zaman yang mempumyai kebudayaan yang terganggu oleh kehancuran, kebingungan, dan kesimpangsiuran. ${ }^{22}$

Aliran in merupakan lanjutan dari filsafat progressivism yang menginginkan kondisi manusia untuk diperbaiki. Aliran ini bercita-cita mengkontuksi kembali kehidupan manusia secara total di semua bidang kehidupan melallui lembaga dan proses pendidikan ${ }^{23}$. Aliran rekonstruksionisme berkeyakinan bahwa tugas penyelamatan dunia merupakan tugas semua umat manusia. Karenanya, pembinaan kembali daya intelektual dan spiritual yang sehat melalui pendidikan yang tepat akan membina kembali manusia dengan nilai dan norma yang benar pula demi generasi yang akan datang, sehingga terbentuk dunia baru dalam pengawasan umat manusia.

\footnotetext{
${ }^{21}$ Abdullah Aly, Op. Cit, Hlm. 48

22 (1985: 340)

${ }^{23}$ Made Pidarta. Loc. Cit, Hlm. 93
} 
Di samping itu, aliran ini memiliki persepsi bahwa masa depan suatu bangsa merupakan suatu dunia yang diatur dan diperintah oleh rakyat secara demokratis, bukan dunia yang dikuasai oleh golongan tertentu. Cita-cita demokrasi yang sesungguhnya tidak hanya teori, tetapi mesti diwujudkan menjadi kenyataan, sehingga mampu meningkatkan kualitas kesehatan, kesejahteraan dan kemakmuran serta keamanan masyarakat tanpa membedakan warna kulit,, keturunan, nasionalisme, agama (kepercayaan) dan masyarakat bersangkutan.

Dan bila alrian filsafat ini masuk pada dasar pengembangan kurikulum, maka sekolah sebagai lembaga pendidikan formal harus menjadi agen utama dalam merekontruksi kehidupan sosial masyarakat. Untuk itu kurikulum haruslah memuat mata pelajaran yang dapat menggugah kesadaran peserta didik falam permasalahan sosial. Untuk itu, mata pelajaran agama, ekonomi, politik dan pendidikan dirasa cocok untuk kurikulum ini. Dan problem solving juga dirasa cocok untuk metode ${ }^{24}$

\section{Konstruktivism}

Filsafat konstruksivism adalah salah salatu filsafat yang menekankan bahwa pengetahuan kita adalah konstruksi kita sendiri. Pengetahuan bukan tiruan dari kenyataan (realitas). ${ }^{25}$ Jean Piaget psikolog pertama yang menggunakan filsafat konstruktivisme, teori pengetahuannya dikenal dengan teori adaptasi kognitif. Konstruktivisme menekankan perkembangan dan konsep dan pengertian yang lebih mandalam, pengetahuan sebagai konstruksi aktif yang dibuat siswa. Jika seseorang tidak aktif membangun pengetahuannya, meskipun usianya tua tetap tidak akan berkembang pengetahuannya.

Dengan demikan, pengetahuan adalah kontruksi dari pengalaman yang dialami oleh menusia.pengetahuan tidak bisa begitu saja dipindahkan dari otak seoragn satu kepada yang lainnya. Siswalah yang mengartikan tentaang apa yang

\footnotetext{
${ }^{24}$ Abdullah Aly, Op. Cit, Hlm. 51

${ }^{25}$ Kokom Komalasari, Pembelajaran Kontekstual, Konsep dan Aplikasi, Bandung: Refika Aditama, 2013, Hlm. 15
} 
telah diajarkan dengan menyesuaikan terhadap pengelaman-pengalaman mereka sendiri. ${ }^{26}$

Menurut Zahorik, terdapat lima elemen belajar yang kontruktivistik yang mana pertama adalah pengaktivan pengetahuan yang sudah ada. Lalu yang kedua memperoleh pengetahuan baru kemudia memperhatikan detaialnya. Selanjutnya yang ketiga pemahaman pengetahuan dengan menyusun konsep sementara. Setelah itu mempraktikan pengetahuan dan pengeetahuan tersebut dan yang terakhir merefelksikan strategi pengembangan pengetahuan itu. ${ }^{27}$

Penulis lebih tertarik kepada aliran filsafar ini karena nilai lebih dari filsafat ini adalah kekuatan dalam membangun kebebasan serta presepsi yang positif terhadap belajar. Atau dengan kata lain, pembelajaran Konstruktivistik tidak teacher centered atau student centered, tetapi memposisikan keduanya setara dalam proses pembelajran sehingga dalam hal ini metode pembelajaran yang sesuai agaknya adalah pembelajaran ilmiah. Yang mana metode pembelajaran ilmiah menjadi senjata dalam proses pembelajran Kurikulum 2013. Sehingg filsafaat ini menurut hemat penulis selauai menjadi dasar pengembangan kuriklum 2013 yang akan di jelaskan pada susb bab yang akan datang.

6. Eksestentialism

Filsafat pendidikan eksententialism berpendapat bahwa kenyataan dan kebenaran adalah eksistensi individu iu sendiri. Oleh karena itu, alirana filsafat ini menghendaki pendidikan selalu melibatkan peserta didik dalam mencari pilihan untuk memenuhi kebutuhannya masing-masing dan menemukan jati diri, karena setiap individu adalah unik dan memiliki tanggung jawab atas dirinya dan nasibnya sendiri. ${ }^{28}$

Seseorang akan menjadi tahu tentang sesuatu melalui pengelaman. Dal ini bergantung kepada tingkat kesadaran masing-masing untuk mencar pengalaman.

\footnotetext{
${ }^{26}$ A. Lorsbach dan K. Tolbin, Constructivism as a Referent for Science Teaching, NARS Reseach Matters to the Science Teacher. No. 30, 1992, Hlm. 67

27 John. A Zahorik, Contructivist Teaching, Bloomongton Indianan: Phil Delta Kappa Educatioanal Foundation, 1995, Hlm. 14-22

${ }^{28}$ Muhaimin, Op. Cit. Hlm. 80
} 
Kebenaran adalah relatif bergantung kepada keputusan setiap individu. Begitu pula nilai-nilai juga ditentukan oleh individu. Orang tidak perlu beradaptasi kepada nilai sosial agar eksistensi dirinya tidak hilang.

Pendidikan dalam pandangan aliran ini bertujan mengembangkan kesadaran individu, memberikan kesempataan untuk bebas memilih etika, mendorong pengembangan pengetahuan diri sendiri, bertanggung jawab sendiri dan mengembangkan komitmen diri. Materi pelajaran harus memberikan kesempatan aktif sendiri dan peserta didik mendapatkan pengelaman sesuai dengan perbedaan-perbedaan individual mereka. Guru haruslaj bersifat demokratis dengan teknik mngajar tidak langsung. ${ }^{29}$

Kurikulum yang menganut filsafat ini enempatkan guru sebagai fasilitator yang membantu peserta didik dalam menemukan jati dirinya yang unik. Dalam hal ini guru memperlakikan setiap individu peserta didik dan menghargai aspek emosional dan rasional maing-masing peserta didik agar mereka mampu menghargai diri mereka secara tepat. Karena itu, metode pembelajran yang sesuai dengan karakter kurikulum ini haruslah metode pembelajran yang bersifat indiviual. Mata pelajrannya pun harus terbuka dengan minat serta bakat masingmasing peserta didik. ${ }^{30}$

Filsafat ini kurang begitu pas diterapkan di negara yang berkembang yang mana pendidikan di negara berkembang pada umumnya belum mampu mengakomodir semua minat dan kebutuan peserta didik. Selian itu. karena faktor sarana dan prasarana yang masih minim serta human Resorce guru yang belum bisa menjadi fasilitatro bagi keunikan individu peserta didik menjadikan hambatan kurikulum yang menganut aliran ini.

\section{Dasar Filosofis Kurikulum 2013 berbasis Multikultural}

Kurikulum 2013 merupakan kurikulum tetap diterapkan oleh pemerintah untuk menggantikan Kurikulum Tingkat Satuan Pendidikan yang telah berlaku selama

\footnotetext{
${ }^{29}$ Made Pidarta, Op. Cit, Hlm. 94

${ }^{30}$ Abdulah Aly, Op. Cit, Hlm. 48
} 
kurang lebih 6 tahun. Kurikulum 2013 masuk dalam masa percobaanya di tahun 2013 dengan menjadikan beberapa sekolah menjadi sekolah percobaan. Di tahun 2014, Kurikulum 2013 sudah diterapkan di Kelas I, II, IV, dan V sedangkan untuk SMP Kelas VII dan VIII dan SMA Kelas X dan XI. Diharapkan, pada tahun 2015 telah diterapkan di seluruh jenjang pendidikan. Kurikulum 2013 memiliki tiga aspek penilaian, yaitu aspek pengetahuan, aspek keterampilan, dan aspek sikap dan perilaku. Di dalam Kurikulum 2013, terutama di dalam materi pembelajaran terdapat materi yang dirampingkan dan materi yang ditambahkan

Menurut penulis pribadi, aliran yang tepat untuk menjelaskan Kurikulum 2013 adalah aliran konstruktivisme. Karena Kurikulum 2013 dan aliran filsafat konstruktivism mempunyai kesamaan dalam menekankan perkembangan dan konsep dan pengertian yang lebih mandalam, pengetahuan sebagai konstruksi aktif yang dibuat siswa. Jika seseorang tidak aktif membangun pengetahuannya, meskipun usianya tua tetap tidak akan berkembang pengetahuannya. Penerapan pendidikan dengan pola konstruktivisme diwujudkan dengan mengajak siswa secara aktif membangun konsep-konsep kognitif. Guru tidak sekedar memberi, namun siswa mencari secara aktif, dan mengembangkannya.

Pembelajaran konstruktivisme melibatkan guru yang konstruktif pula. . Satu contoh misalnya dalam pembelajaran sains, siswa terlebih dahulu diajak untuk mengamati fenomena-fenomena alam yang ada seperti pelangi, banjir, merebaknya hama tanaman tertentu. Melalui fenomena yang ada, guru mengarahkan siswa untuk mencari penyebabnya. Siswa menemukan sendiri penyebab terjadinya pelangi, banjir ataukah hama Guru tidak hanya memberi pengetahuan kepada siswa, tetapi guru membantu siswa membangun sendiri pengetahuan dalam benaknya, dengan memberikan kesempatan siswa untuk menentukan atau menerapkan ide-ide mereka sendiri. Guru memberikan kepada siswa anak tangga untuk membawa siswa kepada pemahaman yang lebih tinggi dan siswa harus memanjat sendiri anak tangga tersebut.

Proses belajar berdasarkan konstruktivisme, meliputi: (1) belajar tidak hanya sekadar menghafal, akan tetapi siswa harus mengonstruksikan pengetahuan di benak mereka sendiri; (2) siswa belajar dari mengalami, di mana siswa mencatat sendiri 
pola-pola bermakna dari pengetahuan baru, bukan diberi begitu saja oleh guru; (3) pengetahuan yang dimiliki seseorang terorganisasi dan mencerminkan pemahaman yang mendalam tentang sesuatu persoalan (subject matter) (4) pengetahuan tidak dapat dipisah- pisahkan menjadi fakta-fakta atau proposisi yang terpisah, tetapi mencerminkan keterampilan yang dapat diterapkan; (5) manusia mempunyai tingkatan yang berbeda dalam menyikapi situasi baru; (6) siswa perlu dibiasakan memecahkan masalah, menemukan sesuatu yang berguna bagi dirinya, dan bergelut dengan ide-ide; (7) proses belajar dapat mengubah struktur otak. Perubahan struktur otak itu berjalan terus seiring dengan perkembangan organisasi pengetahuan dan keterampilan seseorang. ${ }^{31}$

Selain pandangan pribadi penulis, dalam konteks ke-Indonesia-an, para perancang Kuriklum 2013 menggunakan filsafat pancasila sebagai dasar pengambangan kurikulum. Hal ini tertuang dalam Undang-uandang Didiknas No. 20 Tahun 2003 bab II pasal 2 yang menyebutkan "Pendidikan Nasional berdasarkan Pancasila dan Undang-undang Dasar Negara Republik Indonesia Tahub 1945"32

Pemasyarakatan dan pembudayaan Pancasila dengan memasukkan kedalam kurikulum melalui dasar filsafatnya tidak langsung dan menjamin efektifitas serta efisiensi pekerjaan itu.sebab para pelaku pendidikan di indonesia secara jelas tidak tahu bagaimana memasukkannyan, bagian mana yang dimasukkan dan kapam dimasukkan. Untuk itu, rincian tentang pasal 2 dilanjutkan oleh peraturan pemerintah RI No 19 Tahun 2005 tantang Standar Nasional Pendidikan yang mana para perancang kurikulummempeerhatikan 5 kelompok mata pelajaran yang harus diberikan kepada peserta didik. Kelima kelompok mata pelajaran terebut meliputi(1) Kelompok mata pelajaran agama dan akhlak mulia, (2) Kelompok mata pelajran kewargannegaraan dan kepribadian, (3) kelompokk mata pelajaran ilmu pengetahuan

${ }^{31}$ Dikjen Dikdasmen Depdiknas RI, Pendekatan Kontektual, Contektual Teaching and Learning (CTL), Jakarta: Ditjen Dikdasmen Depdiknas, 2003, Hlm. 3

${ }^{32}$ Undang-undang No. 20 Yahun 2003 tentang Sistem pendidikan Nasional dan Penjelasannya, Yogyakarta: Media Wacana, 2003, Hlm. 12 
dan teknologi, (4) Kelompok mata pelajaran estetika, dan (5) Kelompok mata pelajaran jasmani, olah raga dan kesehatan. ${ }^{33}$

Penggunaan filsafat Pancasila menjadi Dasar pengembangan kurikuk memberikan kesampatan kepada siswa untuk belajra dan tidak melupak akar budaya siswa itu berasal. Selain itu, dapat menumbuhkan nilai nasionalis dalam mengemangkan nilainilai budaya yang digunakan dalam kehidupan sehari-hari. ${ }^{34}$

Selain kedua filsafat diatas, Kurikulum 2013 juga dapat dikembangkan dengan dasar filsafat yang telah penulis uraikan pada sub bab terdahulu. Jika ditinjau dari macam aliran filsafat pembentuk utama kurrikulum dan landasan filosofis Kurikulum 2013 diatas, maka akan terlihat bahwa kurikulum 2013 mencoba mengabungkan/mengeklektikan semua aliran filsafat yang ada. Hal itu dilakukan mengingat makin peliknya persoalan bangsa dan Negara Indonesia dewasa ini. Melalui pengabungan itu diharapkan menjawab dan mengakomodir semua tantangan dan kebutuhan pendidikan di Indonesia.

Dan dalam pengembangannya, bila kurikulum 2013 dibenturkan dengan aliran filsafat multikulturalisme, tentunya akan lahir sebuah kurikulum 2013 berbasis multikulturalisme. Dalam proses ini, kita akan melihat bagaimana nilai-nilai multikultural masuk dan mewarnai serta mendasari pengembangan kurikulum 2013. Sebagaimana pembahasan pertama kita, bahwa filsafat multikulturalisme lahir karena teori keadilan serta teori kebebasan, maka nilai keadilan dan kebebasan tentunya menjadi dominan dalam pengembangan kurikulum 2013 berbasis multikultural. Sehingga dasar kurikulum 2013 haruslah mengemas nilai keadilan dan kebebasan.

Karena pendidikan multikultural adalah pendidikan yang dapat dirasakan oleh beberapa kultur yang berbeda sehingga kedua nilai ini wajib mutlak adanya. Pendidikan multikultural hakaketnya juga merupakan upaya melembagakan filsafat multikulturalismeya dalam sistem pendidikan dengan membumikan prinsip persamaan, saling menghargai, menerima dan memahami serta adanya komitmen

\footnotetext{
${ }^{33}$ Peraturan Pemerintah RI No 19 Tahun 2005 Tantang Standar Nasional Pendidikan, Hlm. 6 ${ }^{34}$ Djunaidi Ghoni, Desain Pengembangan Kurikulum Pendidikan Agama Islam Multikultural dalam Kajian ayng tidak dipublikasikan, Hlm. 4
} 
moral terhadap keadilan social, sehingga dalam hal ini, karaktiristik utama multiklturalisme dalam praksis pendidikan yaitu; (1) belajar hidup dalam perbedaan, (2) membangun saling percaya (mutual Trust), (3) memelihara saling pengertian (mutual Understanding) (4) menjunjung sikap saling menghargai (mutual respect), (5) terbuka dalam berfikir, (6) apresiasi dan interdepensi, dan (7) resolusi konflik dan rekonsiliasi nirkekerasan. ${ }^{35}$

\section{E. Kesimpulan}

Dari pembahasan diatas dapat kita tarik senuah benang merah bahwa akar dari filsafat multikulturalisme adalah teori keadilan John Rawls dan teori kebebasan Charles Taylor sehingga dalam multikulturalisme nilai keadilan dan kebebasan menjadi dominan. Pendidkan multikultural buka hanya sebuah trending topik atau budaya latah para pakar pendidikan. Lebih dari itu, pendidikan multikultural merupakan upaya para pakar pendidikan menformulasikan pendidikan yang dapat dinikmati berbagai kalangan dan tentunya menjadi solusi permasalahan pendidikan yang lazim biasa didengar seperti diskriminasi, konflik budaya dan ras serta golongan. Sehingga dalam pengembanganngya, pendidikan mutikultural haruslah memakai filsafat multikulturalise dalam dasar pengembangannya.

Dan juga bila pendidikan multikultural coba kita terapkan dalan konteks keIndonesia-an, maka akan kita dapati sebuah tawaran dari penulis dengan istilah kurikulum 2013 berbasis multikultural sebagaiman pembahasan bagian terakhir. Dan hemat penulis, penerapan multikulralisme dalam pendidikan sehingga menjadi "pendidikan multikultural" sangatlah tepat mengingat Indonesia adalah negara multikultur terbesar di dunia. Terlepas dari pro kontra pendidikan multikultural, sebelum menerapkan konsep pendidikan multikultural, tentunya terlebih dahulu kita formulasikan kurikulum yang berbasis multikultural dengan filsafat multikulturalisme sebagai roh kurikulum tersebut.

35 Zakiyuddin Baidlowy, Pendidikan Agama Benvawasan Multikulturalisame, Jakarta: Erlangga, 2005, Hlm. 75-84. 


\section{DAFTAR RUJUKAN}

Abdullah Aly, Pendidikan Islam Multikultural Pesantren, Telaah terhadap Kurikulum Pondok Pesantren Islam Modern Assalam Surakarta, Yogyakarta: Pustaka Pelajar, 2011

Dikjen Dikdasmen Depdiknas RI, Pendekatan Kontektual, Contektual Teaching and Learning (CTL), Jakarta: Ditjen Dikdasmen Depdiknas, 2003

Djunaidi Ghoni, Desain Pengembangan Kurikulum Pendidikan Agama Islam Multikultural dalam Kajian ayng tidak dipublikasikan

HAR Tilaar, Multikulturalisme, Tantanagan-tantangan Global Masa Depan dalam Tranformsi Pendidikan Nasional, Jakarta: Grasindo, 2004

John. A Zahorik, Contructivist Teaching, Bloomongton Indianan: Phil Delta Kappa Educatioanal Foundation, 1995

Kokom Komalasari, Pembelajaran Kontekstual, Konsep dan Aplikasi, Bandung: Refika Aditama, 2013. Lorsbach dan K. Tolbin, Constructivism as a Referent for Science Teaching, NARS Reseach Matters to the Science Teacher. No. 30, 1992

Made pidarta, Landasan Kependidikan, Stimulus Ilmu Pendidikan Bercorak Indonesia, Jakarta: Riena Cipta , 2013

Muhaimin, Pengembangan Kurikuum Pendidikan Agama Islam, di Sekolah Madrasah dan Perguruan Tinggi, Jakarta: Pt. Raja Grafido Persada, 2005

Peraturan Pemerintah RI No 19 Tahun 2005 Tantang Standar Nasional Pendidikan

Ridha Ahida, Konsep Keadilan pada Masyarakat Multikultural dilihat dari Perspektif John Rawls dan Will Kymlicka, dalam Perpustakaan Digital Universitas Indonesia,

Sholeh Hidayat, Pengembangan Kurikulum Baru,Bandung: PT. Remaja Rosda Karya, 2015

Undang-undang No. 20 Yahun 2003 tentang Sistem pendidikan Nasional dan Penjelasannya, Yogyakarta: Media Wacana, 2003

Yusuf Akhyar. Multikulturalisme dalam Perspektif Filsafat. Kajian dalam seminar "Student Circle" Pusat Studi Islam Paramadina dan Islamic College for Advance Studies (ICAS) Jakarta, 12 Maret 200

Zakiyuddin Baidlowy, Pendidikan Agama Benvawasan Multikulturalisame, Jakarta: Erlangga, 2005 